\title{
Research Article: Impact of frontline demonstration of SRI technology of paddy cultivation in Navsari district of Gujarat
}

\author{
K.A. SHAH, B.M. TANDEL* AND C.K. TIMBADIYA
}

Article Chronicle :

SUMMARY : The front line demonstration on SRI technology of paddy cultivation was conducted for two year (2012-13 and 2013-14) on farmers field in two talukas of Navsari district in Kharif season. It was observed that average yield performance of SRI technology of 10 and 36 demonstrations in area of 2.5 and 8.6 hectares of 8064 and $8168 \mathrm{~kg} / \mathrm{ha}$ during the year 2012-13 and 2013-14, respectively. The percentage increase in demonstration yield over local cultivation practices was 58.6 and 70.6 per cent during the year 2012-13 and 2013-14, respectively. The farmers have incurred average higher gross return of Rs. 101476/ha and benefit cost ration of 3.06 through these demonstrations over local paddy cultivation practices, which was recorded Rs.. $61607 /$ ha and 2.21, respectively. The average additional gain of Rs. 39869/ha was obtained by farmers through these demonstration. Results of the demonstration had shown that the SRI technology of paddy cultivation obtained higher productivity of paddy.

How to cite this article : Shah, K.A., Tandel, B.M. and Timbadiya, C.K. (2015). Impact of frontline demonstration of SRI technology of paddy cultivation in Navsari district of Gujarat. Agric. Update, 10(1): 52-54.

\section{KeY WORDS :}

SRI, Demonstration, Impact, Paddy

Author for correspondence :

\section{B.M. TANDEL}

Krishi Vigayn Kendra

(N.A.U.), NAVSARI

(GUJARAT) INDIA

See end of the article for

authors' affiliations 